\title{
Gas chromatographic determination of some carboxylic acids: comparison between solution and headspace analysis
}

\author{
Birutė Bugelytè, \\ Karolina Ilonina, \\ Vilius Poškus, \\ Vida Vičkačkaitė \\ Department of Analytical \\ and Environmental Chemistry, \\ Vilnius University, \\ 24 Naugarduko Street, \\ 03225 Vilnius, Lithuania
}

\begin{abstract}
Direct and headspace gas chromatographic analysis is compared for the determination of lactic, oxalic, succinic, malic and citric acids. For better chromatographic behaviour, prior to GC analysis carboxylic acids were derivatized using BSTFA as a silylation reagent. Three solvents - acetone, diethyl ether and dimethylformamide - were tested as a derivatization medium and DMF was considered as the best. Derivatization conditions were optimized and analytical characteristics of the direct gas chromatographic determination of analytes in solutions were determined. The method was applied for the determination of citric acid in food. For the analytes dissolved in DMF, the headspace gas chromatographic determination was not sensitive enough. Concentrations of the derivates in the headspace were very low, thus the limits of detection were high and the method was not of practical use. On the other hand, headspace gas chromatography can be applied for identifying of carboxylic acids in solid samples.
\end{abstract}

Keywords: carboxylic acids, derivatization, BSTFA, headspace, gas chromatography

\section{INTRODUCTION}

Short-chain carboxylic acids occur naturally in most beverages and in food, mainly in fermented products as a result of animal metabolism, hydrolysis and microbial activity during manufacture and storage [1-3]. Also, they are often added as food acidulants, flavouring agents and stabilizers as they reduce bacterial growth by lowering food $\mathrm{pH}$ and thus demonstrate the antimicrobial effect [4, 5]. Even if the quantities of most short-chain organic acids are not regulated and allowed quantum satis [6], their determination is important as the acids affect

\footnotetext{
* Corresponding author. Email vida.vickackaite@chf.vu.lt
}

flavour, texture, aromatic properties and bacterial growth, they show antimutagenic effects, and can serve as authenticity and ageing markers [7-10].

There are many methods to determine shortchain organic acids including titrimetric, spectrophotometric and enzymatic [3, 11]. Individual short-chain carboxylic acids are determined using liquid chromatography, capillary electrophoresis and gas chromatography (GC) [1, , 11]. Direct gas chromatographic determination of shortchain carboxylic acids is aggravated by high polarity of the analytes. However, a derivatization of the acids to less polar compounds with a better gas chromatographic behaviour makes GC analysis 
very attractive due to its simplicity, sensitivity and selectivity. Two derivatization processes - alkylation and silylation - are mainly used [12-14]. However, di- and tri-carboxylic acids are not easily esterified to alkyl esters [13]. For this, silylation is more often applied [15]. Silylation is the introduction of a silyl group into a carboxylic acid molecule in substitution for active hydrogen. Common silylation reagents are trimethylchlorosilane, trimethylsilylimidazole, N,O-bis-(trimethylsilyl) trifluoroacetamide and $\mathrm{N}$-(t-butyldimethylsilyl)$\mathrm{N}$-methyltrifluoroacetamide whereof the two last ones are the most frequently used [16].

Generally analytes should be isolated from a matrix prior to the injection to a gas chromatograph. Volatile compounds can be isolated by distillation-extraction, solvent extraction, dynamic purge and trap and headspace (HS) methods [1721]. Headspace gas chromatography (HS-GC) includes isolation of analytes in the headspace and the subsequent automatic delivery of an aliquot of vapour to the GC system, and is the fastest and cleanest method for analysing volatile organic compounds in solid or liquid matrices [20, 22-24].

The aim of the present work was to develop a simple procedure of derivatization of some short-chain carboxylic acids and to compare their gas chromatographic determination from solutions and from headspace.

\section{EXPERIMENTAL}

\section{Reagents and solutions}

Oxalic ( $\geq 99 \%)$, lactic ( $\geq 98 \%$ ), succinic ( $\geq 99 \%)$, malic ( $\geq 98 \%)$ and citric acids $(\geq 99.5 \%)$, and diethyl ether (DEE) $(\geq 99.5 \%)$ were purchased from Sigma-Aldrich. N,O-Bis-(trimethylsilyl)trifluoroacetamide (BSTFA) $(\geq 98 \%)$, acetone $(\geq 99.9 \%)$ and dimethylformamide (DMF) $(\geq 99.8 \%)$ were purchased from Roth. Stock solutions of oxalic, lactic, succinic, malic and citric acids ( $1 \mathrm{mg} \mathrm{ml}^{-1}$ each) were prepared in acetone, DEE or DMF. Working solutions of carboxylic acids were prepared by dilution of the stock solutions with a corresponding solvent.

\section{Instrumentation and conditions}

The direct gas chromatographic analysis was performed on a Shimadzu GC-2010 Plus series gas chromatograph (Shimadzu, Japan) equipped with a flame ionisation detector. The GC system was equipped with the Ultra 2 capillary column (25 m $\times 0.32 \mathrm{~mm}$ id, $0.52 \mu \mathrm{m}$ film thickness) (Hewlett Packard, USA). Helium was employed as carrier gas with a constant flow of $3 \mathrm{ml} \mathrm{min}^{-1}$. The injector and detector temperature was held at $250^{\circ} \mathrm{C}$. Injection was performed in the split mode (split 10:1). The oven temperature was programmed as follows: $40^{\circ} \mathrm{C}$ for $1 \mathrm{~min}$ and from $40^{\circ} \mathrm{C}$ to $250^{\circ} \mathrm{C}$ at $10^{\circ} \mathrm{C} \mathrm{min}^{-1}$.

The headspace gas chromatographic analysis was performed on a PerkinElmer Clarus 580 series gas chromatograph (PerkinElmer, USA) equipped with a flame ionisation detector. The GC system was equipped with the Elite 5 capillary column $(30 \mathrm{~m} \times 0.25 \mathrm{~mm}$ id, $0.25 \mu \mathrm{m}$ film thickness) (PerkinElmer, USA). Headspace extraction and sample introduction was performed on a PerkinElmer Headspace Sampler Turbomatrix 16 (PerkinElmer, USA) equipped with a balanced pressure system. A headspace vial was positioned in the HS autosampler and equilibrated at the selected temperature. The needle temperature was the same as the headspace vial equilibration temperature. The transition line temperature was $10^{\circ} \mathrm{C}$ higher than the headspace vial equilibration temperature. The settings of the headspace sampler were $2 \mathrm{~min}$ for pressurization and $0.04 \mathrm{~min}$ for injection. Helium was employed as carrier gas with 16.7 psi column head pressure. The injector temperature was held at $110^{\circ} \mathrm{C}$. The detector temperature was held at $250^{\circ} \mathrm{C}$. The GC oven temperature was programmed as follows: $40^{\circ} \mathrm{C}$ for $1 \mathrm{~min}$

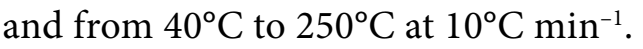

\section{RESULTS AND DISCUSSION}

\section{Direct gas chromatographic determination of carboxylic acids}

As it was mentioned in the introduction, for better chromatographic behaviour prior to GC analysis short-chain carboxylic acids should be derivatized. For derivatization, we have chosen BSTFA, as the reaction can be expected to be complete at room temperature, as BSTFA and its by-products (trimethylsilyltrifluoroacetamide and trifluoroacetamide) are more volatile than many other products, causing less chromatographic interference, and, finally, as hydrogen fluoride, a byproduct of silylation with BSTFA, reduces flame 
ionisation detector fouling [25]. However, BSTFA as other silyl reagents is moisture sensitive, and therefore the solvents and the samples should be dry.

Three solvents - acetone, DEE and DMF - were tested as a derivatization medium. For this, to $1 \mathrm{ml}$ of succinic acid solutions $\left(1 \mathrm{~g} \mathrm{l}^{-1}\right) 50 \mu \mathrm{l}$ of BSTFA was added and after 20 min direct GC analysis was carried out. The analysis revealed that derivatization in acetone was not complete. In the chromatogram obtained after the derivatization a relatively small peak of a succinic acid derivatization product emerges at $12.25 \mathrm{~min}$. However, a huge asymmetric peak of underivatized succinic acid at $10.70 \mathrm{~min}$ is still present as in the chromatogram obtained before derivatization (Fig. 11a). When the solvent acetone was replaced with DEE or DMF, the derivatization was complete (chromatograms of succinic acid in DEE before and after derivatization are presented in Fig. 1b). The boiling point of DEE is $34.6^{\circ} \mathrm{C}$, thus it is difficult to handle, concentrations of a solution may change and thus lead to analytical errors. Because of that, even in the case of direct injection of solutions into a gas chromatograph, diethyl ether is not the first choice solvent. In the case of HS-GC, DEE would not fit at all, since the analytes must be transferred to the headspace by heating and the heating temperature must be lower than the boiling point of the solvent. Obviously, at temperature of less than $34.6^{\circ} \mathrm{C}$, only a very small fraction of derivatized acids would be transferred to the headspace resulting in very high detection limits. Based on the above, we decided in favour of less volatile solvent DMF (boiling point $152^{\circ} \mathrm{C}$ ).
To determine the amount of BSTFA required for derivatization, $5-50 \mu \mathrm{l}$ of BSTFA was added to $1 \mathrm{ml}$ of $1 \mathrm{~g} \mathrm{l}^{-1}$ solutions of oxalic, lactic, succinic, malic and citric acids in DMF, and derivatization was carried out for $20 \mathrm{~min}$. The results of the GC analysis demonstrated that for all the acids $30 \mu \mathrm{l}$ of BSTFA was sufficient.

Further, the effect of derivatization time on the derivatization yield was studied. The acids were subjected to the GC analysis immediately after the addition of BSTFA and after 5 to $60 \mathrm{~min}$ of the addition of BSTFA. The results showed that the duration of derivatization had no effect on the peak areas. Therefore gas chromatographic analysis of the analytes of interest can be performed immediately after the derivatization reagent is added.

In order to correct the loss of analyte during sample handling, an internal standard should be added to the analyte solutions. An internal standard should be a compound that is not normally found in foods (our test items), should be well separated in the chromatogram, but contemporaneously should be eluted at a reasonable time. For four of our analytes, $n$-tridecane was selected as an internal standard. Only in the case of succinic acid, the peak of $n$-tridecane overlapped with the peak of the analyte, so n-tetradecane was chosen (chromatograms are presented in Fig. 2).

For all the analytes, quality parameters such as linearity, limits of detection (LOD) and repeatabilities were determined under the optimized conditions. The calibration curves were drawn with 7 calibration points with three replicate injections

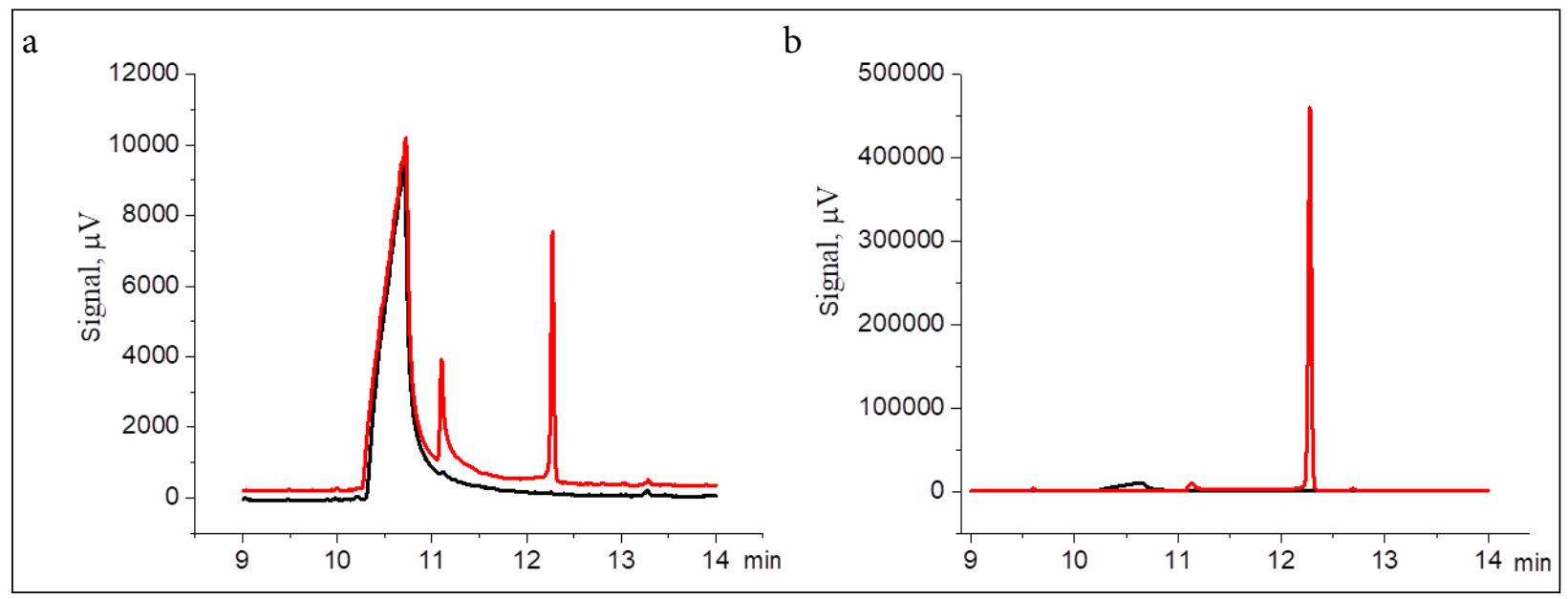

Fig. 1. Chromatograms of succinic acid $\left(1 \mathrm{~g} \mathrm{l}^{-1}\right)$ in acetone (a) and in DEE (b) before (black) and after (red) derivatization. For chromatographic conditions see the Experimental section 


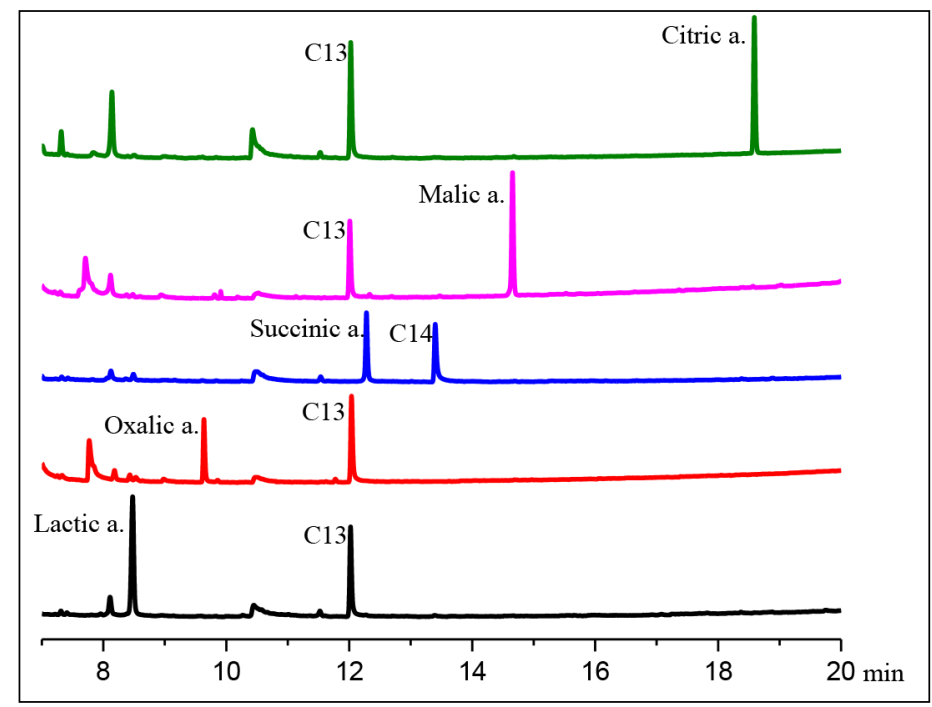

Fig. 2. Chromatograms of derivatized carboxylic acids $\left(1 \mathrm{gl}^{-1}\right)$ in DMF with internal standards. For chromatographic conditions see the Experimental section

and were linear up to $1 \mathrm{~g} \mathrm{l}^{-1}$ for all the analytes. The limits of detection were defined as three times the baseline noise. The repeatabilities were determined by five repetitions analysis. Concentration of an internal standard in the final solutions was $0.01 \mathrm{~g} \mathrm{l}^{-1}$. The retention times, correlation coefficients, limits of detection and relative standard deviations are presented in Table 1 .

Table 1. Retention times (RT), relative standard deviations (RSD), correlation coefficients $\left(R^{2}\right)$ and limits of detection (LOD) of carboxylic acids obtained by direct GC

\begin{tabular}{|c|c|c|c|c|}
\hline $\begin{array}{c}\text { Carboxylic } \\
\text { acid }\end{array}$ & $\begin{array}{l}\text { RT, } \\
\text { min }\end{array}$ & $\begin{array}{c}\text { RSD } \% \\
\left(c=10 \mathrm{mg} \mathrm{l}^{-1},\right. \\
n=5)\end{array}$ & $\mathbf{R}^{2}$ & $\begin{array}{l}\text { LOD, } \\
\mathrm{mg} \mathrm{l}^{-1}\end{array}$ \\
\hline Lactic acid & 8.48 & 2.2 & 0.999 & 0.27 \\
\hline Oxalic acid & 9.61 & 4.9 & 0.996 & 0.55 \\
\hline Succinic acid & 12.25 & 4.5 & 0.997 & 0.59 \\
\hline Malic acid & 14.65 & 4.2 & 0.998 & 0.51 \\
\hline Citric acid & 18.58 & 3.1 & 0.999 & 0.33 \\
\hline
\end{tabular}

\section{Headspace gas chromatographic determination of carboxylic acids}

The next step of the work was to examine the possibility to determine the analytes of interest by headspace gas chromatography. The derivatization conditions were the same as in the case of direct GC determination.

Initially, pure carboxylic acids were examined. For this, $10-20 \mathrm{mg}$ of the acids were weighed into a headspace vial, $30 \mu \mathrm{l}$ of BSTFA was added, the vial was heated for $5 \mathrm{~min}$ at $200^{\circ} \mathrm{C}$ and analysed by headspace gas chromatography under the conditions described in the Experimental section. In the resulting chromatograms the peaks of the derivatized acids were observed. The retention times of them are given in Table 2.

Table 2. Retention times (RT) and limits of detection (LOD) of derivatized carboxylic acids obtained by HS-GC

\begin{tabular}{ccc}
\hline Carboxylic acid & $\mathbf{R T}, \mathbf{m i n}$ & LOD, $\mathbf{~ m ~}^{\mathbf{- 1}}$ \\
\hline Lactic acid & 10.64 & 22 \\
\hline Oxalic acid & 12.22 & 19 \\
\hline Succinic acid & 14.10 & 45 \\
\hline Malic acid & 16.05 & 87 \\
\hline Citric acid & 19.75 & - \\
\hline
\end{tabular}

Further, it was investigated whether the derivatized and dissolved in DMF acids were transferred to the headspace. Since the temperature of the analyte transfer to the headspace must be lower than the boiling point of the solvent $\left(152^{\circ} \mathrm{C}\right)$, the samples were heated at $140^{\circ} \mathrm{C}$. In order to transfer the maximum amount of the analyte to the headspace, the heating time was increased to $20 \mathrm{~min}$. Unfortunately, the concentrations of the derivates in the headspace were very low, thus the limits of detection were high and not of practical use. Citric acid was not detected at all (Table 2). 
In order to obtain lower LOD, the solvent with a higher boiling point should be chosen. On the other hand, headspace gas chromatography is suitable for identifying the acids in dry samples.

\section{Real sample analysis}

The possibility to apply headspace gas chromatography for identifying of carboxylic acids is illustrated by the determination of succinic acid in amber. Amber is a fossil resin derived from coniferous trees. It is found all over the world, but because of different plants from which it originates, it is different in the composition. Succinic acid is found only in Baltic amber [26]. Thus identification of the amber from the Baltic Sea region can be based on the presence of succinic acid in it.

We have analysed the amber collected at the seaside of Palanga, excavated in the Kaliningrad region and originating from Japan. $20-30 \mathrm{mg}$ of the crushed amber was weighed into a headspace vial, $30 \mu \mathrm{l}$ of BSTFA was added, the vial was closed and heated for $15 \mathrm{~min}$ at $200^{\circ} \mathrm{C}$. In Fig. 3 the chromatograms of the derivatized amber from Palanga (a), Kaliningrad (b) and Japan (c) are presented. In the chromatograms $(a, b)$ a peak of succinic acid derivate is evidenced, but it is absent in the chromatogram of Japan amber (C).

Headspace gas chromatography was also applied to detect citric acid in boiled smoked chicken sausages Berlinki (Poland). Citric acid is added to the sausages to regulate the acidity. As BSTFA is moisture sensitive, before derivatization the sausages were crushed and dried at $70^{\circ} \mathrm{C}$ for $5 \mathrm{~h}$. $50 \mathrm{mg}$ of dried and grinded sausages was weighed into the headspace vial, $30 \mu \mathrm{l}$ of BSTFA was added, the vial was closed and heated for $15 \mathrm{~min}$ at $200^{\circ} \mathrm{C}$. A peak of derivatized citric acid is evidenced in the chromatogram (Fig. 4).

Unfortunately, for citric acid quantification, the sensitivity of the headspace gas chromatographic method was not sufficient. Thus the direct GC method was applied. To $0.5 \mathrm{~g}$ of grinded sausages $5 \mathrm{ml}$ of DEE was added, the sausages were extracted for $5 \mathrm{~min}$ and centrifuged for $1 \mathrm{~min}$ at $5000 \mathrm{rpm} .3 \mathrm{ml}$ of the extraction solution was evaporated to dryness, $1 \mathrm{ml}$ of DMF containing an internal standard n-tridecane and $30 \mu \mathrm{l}$ of BSTFA were added and the solution was injected into the gas chromatograph for analysis. A chromatogram of the extract is presented in Fig. 5.

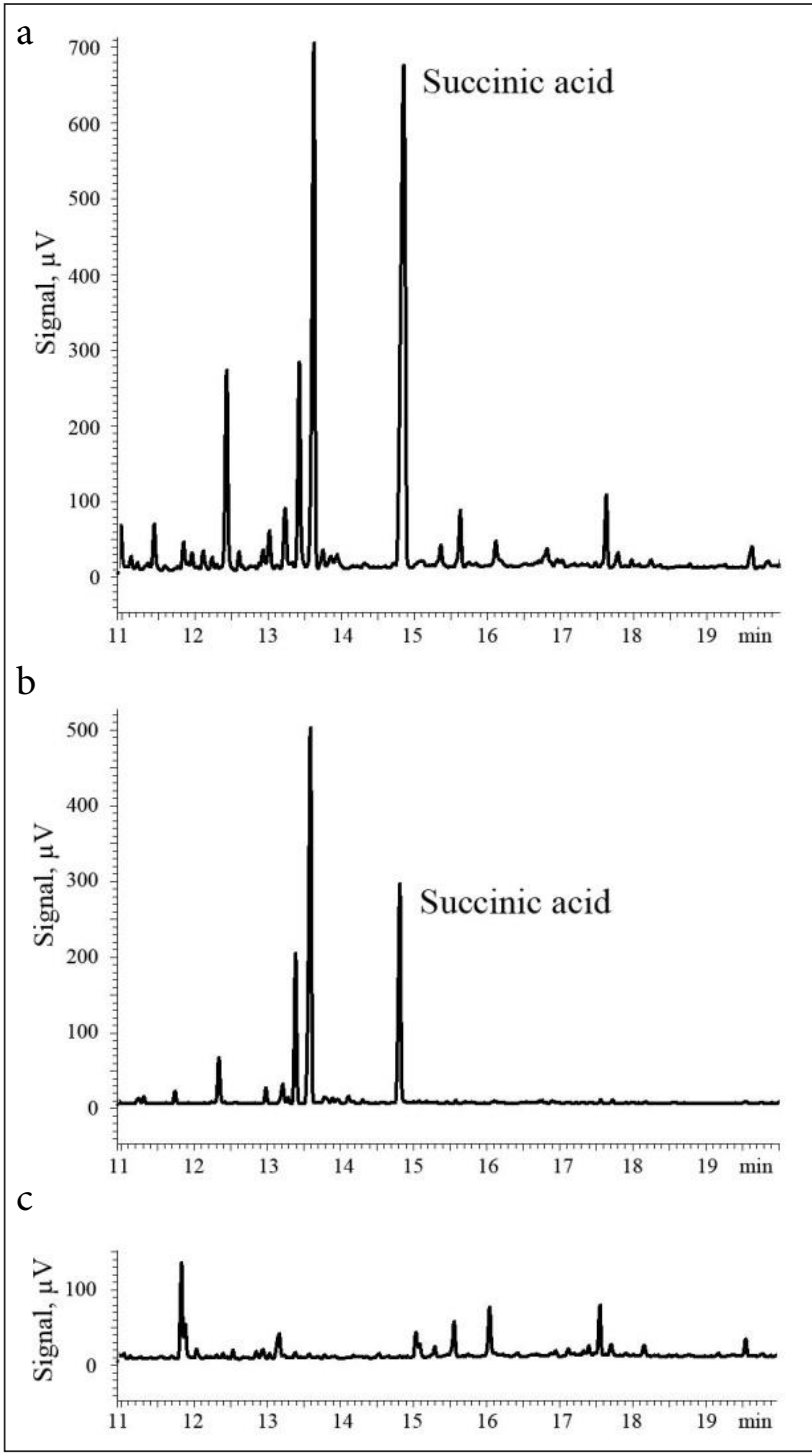

Fig. 3. Chromatograms of the derivatized amber from Palanga (a), Kaliningrad (b) and Japan (c) obtained by HS-GC analysis. Equilibration at $200^{\circ} \mathrm{C}$ temperature for $15 \mathrm{~min}$. For HS-GC conditions see the Experimental section

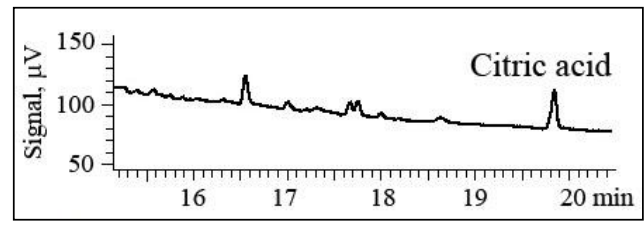

Fig. 4. Chromatogram of derivatized sausages extract obtained by $\mathrm{HS}-\mathrm{GC}$ analysis. Equilibration at $200^{\circ} \mathrm{C}$ temperature for $15 \mathrm{~min}$. For HS-GC conditions see the Experimental section.

It was determined that the sausages contained $0.12 \mathrm{mg} \mathrm{g}^{-1}$ of citric acid. However, differently from the headspace chromatogram (Fig. A), many peaks were observed in the chromatogram of the extract (Fig. 5). It resulted in a bad separation 


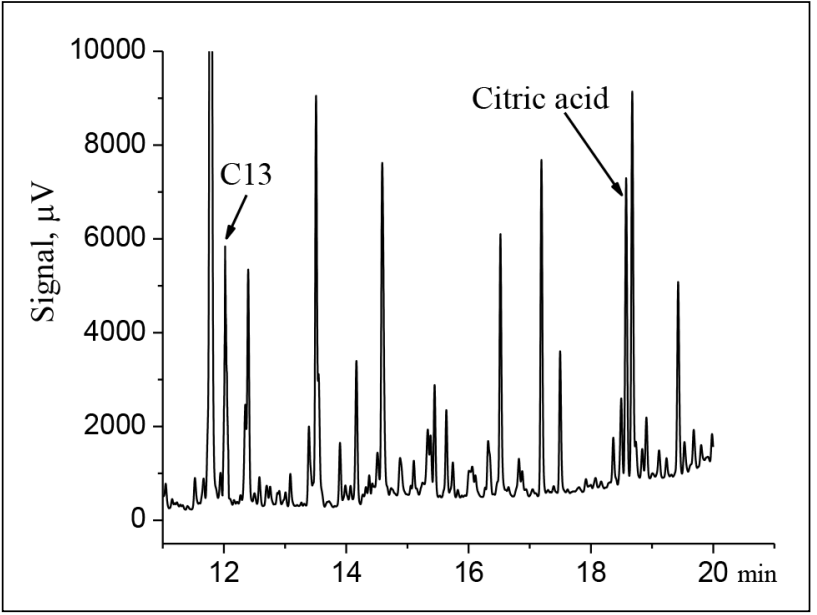

Fig. 5. Chromatogram of the derivatized sausages extract in DMF. For chromatographic conditions see the Experimental section

of the peaks of interest, consequently the repeatability of the results was not good (RSD for three replicate measurements was $21.3 \%$ ).

\section{CONCLUSIONS}

Direct injection of the extracts of complex matrices into a gas chromatograph results in complex chromatograms and in contamination of the chromatographic system. Due to the absence of the interference of low volatile compounds of the matrix, headspace gas chromatography is advantageous for the determination of volatile analytes. Derivatized short-chain carboxylic acids were successfully identified by HS-GC in dry samples. However, for dissolved in DMF and derivatized acids, their concentrations in the headspace were low, thus the limits of detection were high and the method was not of practical use. For HS-GC in order to achieve low detection limits, higher boiling point solvents should be used. Investigations of adequate solvents for the determination of short-chain carboxylic acids using HSGC are in progress.

Received 28 June 2019 Accepted 22 July 2019

\section{References}

1. M. Pereira da Costa, C. A. Conte-Junior, Compr. Rev. Food Sci. Food Saf., 14, 586 (2015).

2. G. Marrubini, A. Pedrali, P. Hemström, T. Jonsson, P. Appelblad, G. Massolini, J. Sep. Sci., 36, 3493 (2013).
3. O. Kritsunankul, B. Pramote, J. Jakmunee, Talanta, 79, 1042 (2009).

4. B. Jurado-Sánchez, E. Ballesteros, M. Gallego, Talanta, 84, 924 (2011).

5. J. G. Zeikus, M. K. Jain, P. Elankovan, Appl. Microbiol. Biotechnol., 51, 545 (1999).

6. Regulation (EC) No. 1333/2008 of the European Parliament and of the Council of 16 December 2008 on food additives, OJ L 354, pp. 16-33, 31.12.2008.

7. G. Turker, B. Kizilkaya, N. Arifoglu, Asian J. Chem., 26, 2443 (2014).

8. M.-H. Yanga, Y.-M. Choong, Food Chem., 75, 101 (2001).

9. A. M. S. Sant'Ana, J. E. S. Ribeiro, F. F. Bezerril, F. L. H. Silva, M. S. Madruga, R. C. R. E. Queiroga, Rev. Mex. Ing. Quím., 16, 781 (2017).

10. M. Cocchi, C. Durante, M. Grandi, P. Lambertini, D. Manzini, A. Marchetti, Talanta, 69, 1166 (2006).

11. R. Fernández, R. M. Dinsdale, A. J. Guwy, G. C. Premier, Crit. Rev. Environ. Sci. Technol., 46, 209 (2016).

12. M. C. Pietrogrande, D. Bacco, M. Mercuriali, Anal. Bioanal. Chem., 396, 877 (2010).

13. P. Hušek, P. Šimek, P. Matucha, Chromatographia, 58, 623 (2003).

14. M. A. Farajzadeh, N. Nouri, P. Khorram, TRAC, 55, 14 (2014).

15. C. Schummer, O. Delhomme, B. Appenzeller, R. Wennig, M. Millet, Talanta, 77, 1473 (2009).

16. F. Orata, in: M. A. Mohd (ed.), Advanced Gas Chromatography - Progress in Agricultural, Biomedical and Industrial Applications, InTech (2012) https:// www.intechopen.com/books/advanced-gas-chromatography-progress-in-agricultural-biomedicaland-industrial-applications|.

17. G. Arora, F. Cormier, B. Lee, J. Agric. Food Chem., 43, 748 (1995).

18. L. Alonso, M. J. Fraga, J. Chromatogr. Sci., 39, 297 (2001).

19. Z. Guker, A. Tasdelen, H. Senol, N. Kerimoglu, U. Temel, GIDA, 34(3), 137 (2009).

20. A. Arezou, M. Shuhaimi, A. M. Yazid, M. Rosfarizan, Int. J. Food Prop., 12, 808 (2009).

21. U. Ravid, M. Elkabetz, C. Zamir, K. Cohen, O. Larkov, R. Aly, Flavour Frag. J., 25, 20 (2010).

22. H. Cheng, Crit. Rev. Food Sci., 50, 938 (2010).

23. V. Vičkačkaite, D. Jasas, Chemija, 27(2), 109 (2016).

24. B. Kolb, L. S. Ettre, Static Headspace-Gas Chromatography: Theory and Practice, 2nd edn., Wiley, New Jersey (2006).

25. BSTFA Product Specification https://www.sigmaaldrich.com/content/dam/sigma-aldrich/docs/ Aldrich/General_Information/bstfa.pdf].

26. J. H. Langenheim, Plant Resins. Chemistry, Evolution, Ecology, and Ethnobotany, Timber Press, Portland (2003). 
Birutė Bugelytė, Karolina Ilonina, Vilius Poškus, Vida Vičkačkaitè

KAI KURIŲ KARBOKSIRŪGŠČIŲ DUJŲ

CHROMATOGRAFINIS NUSTATYMAS: TIRPALO IR VIRŠERDVĖS ANALIZĖS PALYGINIMAS

Santrauka

Pieno, oksalo, gintaro, obuolių ir citrinų rūgštims nustatyti palyginta tirpalų ir viršerdvès dujų chromatografinè analizè. Prieš dujų chromatografinę analizę karboksirūgštys buvo derivatizuotos sililinimo reagentu BSTFA. Ištirti trys tirpikliai - acetonas, dietilo eteris ir dimetilformamidas. Tinkamiausiu pasirinktas dimetilformamidas. Optimizuotomis derivatizacijos sąlygomis buvo nustatytos tirpalų dujų chromatografinio metodo analizinès charakteristikos. Metodas buvo pritaikytas citrinų rūgščiai maiste nustatyti. Deja, dimetilformamide ištirpintų karboksirūgščių viršerdvès dujų chromatografinès analizès metodo aptikimo ribos buvo labai didelès, ir metodas kiekybinei analizei praktinès vertès neturèjo. Viršerdvès dujų chromatografija buvo pritaikyta karboksirūgštims identifikuoti kietuose mėginiuose. 